\title{
1. Global crises and their effects on tourism economy
}

\author{
Ŏguz Türkay and Burak Atasoy
}

\section{INTRODUCTION}

The periods when liberal tendencies continue globally, industrial development continues on its normal course, and international trade is not interrupted, are the periods when tourism is also strong. Crises that interrupt these periods affect tourism foremost and most strongly. As tourism is sensitive to all kinds of crises, it has focused the search for crisis management practices on this industry. It is also of great importance for such a large and influential industry to identify possible measures and solutions for tourism against different crisis occurrences that cause shrinkages throughout the industry by suddenly and drastically reducing demand.

A crisis is considered as an abnormal situation. The likelihood of going beyond the normal, encountering a new normal after the crisis - even for temporary periods - is often strong. In this respect, seeing and understanding the hints of the new normal is critical for both businesses and the tourism industry in general. In fact, depending on the nature of the crisis, its impact is expected to be limited to a particular business, sector or geography. But crises have an expansionist character, which affects not only the area where they emerge, but other economies and people. However, the phenomenon of global integration of processes, which we call globalization, also globalizes problems and crises. Thanks to the global networks and the media, the fact that the situation of those who face the crisis is more visible creates a risk perception, crisis awareness, and fear and anxiety in those who are not directly related to the crisis, and this situation may even exacerbate the situation and reduce the opportunity and power to cope with the crisis (Mukherjee and Alpert, 2006). It leads to a response beyond the seriousness of crisis in consumption areas such as tourism, where the perceptual characteristic of demand is determinant.

The rapid and profound effects of crises on the functioning of the tourism industry have also attracted the attention of academics. In the initial studies conducted on crisis in tourism, it is seen that a perspective was adopted investigating the effects on tourism by dealing with certain crises (Solomon and George, 1976; Hope, 1980), that the concepts of planning and policy against the crisis were highlighted (Arbel and Bargur, 1980), and that solutions applied in the crises experienced in some specific tourism destinations were introduced (Scott, 1988).

While Sönmez et al. (1999) define crisis management in tourism as a practice in itself and enumerate its critical steps, Blake and Sinclair (2003) clarify the concept and policies of "tourism crisis management" through the situation after September 11. As a proof of this maturity displayed by the literature, international book studies that analyze the tourism industry from the perspective of security and crisis management (Mansfeld and Pizam, 2006; Henderson, 2007; Laws et al., 2007) were published in the first decade of the 2000s. Due to both the maturation of the subject and the increase of crises affecting the performance of the destinations and the demand for tourism in a multidimensional way, the early 2000 s were the 
years when the issue of crisis management in tourism received wide attention and different studies were discussed. Jiang et al. (2019) also highlight this increase. This situation points to a literature that develops over time on what is defined as a crisis in tourism, the conditions that occur before and after the crisis, the critical stages of the process of managing the effects that occur due to these conditions, and possible solutions. Current studies focus on critical issues such as signal detection, organizational learning in the crisis period, destination governance and social media solutions (Paraskevas and Altinay, 2013; Ghaderi et al., 2014; Çakar, 2018; Park et al., 2019).

The current development of the literature has increased the volume of information on crises in tourism. It is a fact that every new crisis has its unique conditions. The reinterpretation of existing knowledge within the scope of new crises and new conditions will both contribute to the literature and facilitate the practical use of the theory by guiding the practice.

\subsection{CONCEPTS AND THEORIES RELATED TO CRISIS}

\subsubsection{Concept of Crisis and the Sources}

It is considered that the etymological roots of the word "crisis" date back to Ancient Greek. In Ancient Greece, the concept of crisis ( $\kappa \rho \iota \varsigma \iota \varsigma)$ was used to mean "judgment" or "decision." A specific moment, period or turning point when a situation evolved into a positive or negative result was expressed by the concept of "crisis" (Milašinović and Kešetović, 2008). In the periods when it was first used, the concept of the crisis was mostly addressed in medical cases, and it was associated with health for a long time. However, it is understood that the concept of the crisis assumed different meanings in the seventeenth century. The crisis now became a concept that was expressed not only in health but also in different fields such as politics, economy, history and psychology. On the other hand, towards the end of the eighteenth century, this term acquired a religious and symbolic meaning. Relating the events that occurred during the French and American revolutions to crisis explains the new meanings attributed to this term (Koselleck and Ritcher, 2006). Therefore, it can be considered that the events and facts experienced by societies are behind the meanings gained by the concept of crisis in different periods. While only medical crises drew attention due to major health problems in the early periods, the experience of economic and political problems in the Middle Ages led the concept of crisis to be interpreted differently.

Glaesser (2003) refers to two approaches that define the concept: in an individual and a collective scope. In the individual scope, definitions have been given such as the critical point (in the field of health) at which a disease process transforms between life and death states; and the existence or perception of a difficulty exceeding the endurance of a person (in the field of psychology). In response to these definitions, attention is drawn to the problem-solving capacities of individuals in crises. In the collective scope, a social phenomenon (social sciences) in which national interests are endangered when conditions of war begin to emerge; a change in political relationship patterns (politics); external economic shocks and the wear or break tendency of the economic cycle (economy) have been defined. As a result of dealing with the crisis at the collective level, collective decision-making processes come to the fore.

It is not easy to give a general definition of the concept of crisis in terms of social sciences. Besides, there is no consensus on the meaning of the concept and the limits of this interpre- 
tation. The degree of "crisis" of the current situation or the events faced may vary depending on the perspective (Aktan and Şen, 2001; Hamidovic, 2012). This is because people who work in many different fields - such as sociology, public administration, political science, international relations, psychology and computer science - each define the concept of crisis. Nevertheless, crises are dealt with at the level of countries and/or economies in the field of sociology, public administration and political science, and at the level of organizations in the field of business sciences, and are accepted as unforeseen situations whose causes and effects are unknown. A crisis is a phenomenon that occurs from time to time - not often but poses a major threat to countries, businesses and institutions (Quarantelli, 1988). For an organization, it may occur due to mismanagement or bad leadership, financial fraud, data loss, destruction of the workplace due to fire or flood without any security such as insurance, and so on. At the country level, it may develop due to factors such as war or terrorism, political upheavals, crime waves, climate changes and natural disasters (COMCEC, 2017). Crises at all levels require some decisions to be made. Although these decisions involve short-term steps, they can have long-term effects. In this context, it can be said that crises have vital importance for every environmental element with their potency. In this sense, certain crisis definitions are provided by considering all crisis environments. Pearson and Clair (1998) refer to a crises as periods that threaten the vital activities of organizations, institutions and countries; that have long-term effects although they are short-term; when the causes, effects and solutions are unknown; and when sudden decisions must be made.

In another narrative, in an organizational sense, the crisis is expressed as a state of stress, which is not known in advance, that needs to be immediately responded to by the organization and threatens the existing values, goals and assumptions by making the organization's prevention and adaptation mechanisms inadequate (Tekin, 2016). Beirman (2003) deals with crises as events that cannot be controlled. This view emphasizes that the situations caused by factors such as mismanagement for businesses, inadequate public relations or product errors, and so on, are controllable by the business authorities, but that it is not possible to control events such as disasters, epidemics and global financial crises that affect the destinations. In this sense, crises should be considered as situations whose effects exceed individuals and businesses.

A more comprehensive explanation can be provided for the definition of the crisis for tourism destinations. Developments that threaten tourism operations and related business areas; damage the reputation of the destination for safety, attractiveness and comfort by negatively affecting the perceptions of visitors; disrupt the local travel and tourism economy; and interrupt the continuation of operations (Sönmez et al., 1994, cited in Glaesser, 2003) by weakening the demand and flow of tourists, are crises for destinations.

Despite the differences in definitions, Milašinović and Kešetović (2008) draw a comprehensive map of crisis characteristics by pointing out the common points of the definitions. According to the researchers, the content of the concept of crisis includes:

- negativity, that is, an emergency incident caused by factors that are not under control, endanger the life or health of people or animals, and cause material damage;

- an unexpected event, that is, an unforeseen event;

- extending beyond the borders of the technical-technological facility where it occurred, a mishap caused by the human factor, including technology;

- a big event, that is, emergencies representing any event whose activities and consequences could not be prevented, mitigated or corrected by using the available resources, such as 
death, injuries, property damage, environmental changes and disruptions in the normal functioning of society.

The critical point in defining the concept of crisis is the matter of which events will be called crises. This leads to discussions about which factors lead to a crisis, and what types of sources the events called crises have emerged from. From this point of view, it is seen that the difficulty in defining the concept is partly due to the abundance and diversity of crisis sources. Identification and classification of these sources also mean the classification of crises.

The phenomenon of crisis can arise from a variety of different factors. The UNWTO (2011) classified crisis mainly into five types: environmental events (geological events such as earthquake, volcano, and so on, and extreme weather such as flood, hurricane, and so on); societal-political events (coups, terrorism, and so on); health-related events (H1N1, SARS, COVID-19, and so on); technological events (transportation accidents, and so on); and economic events (fiscal crisis, exchange rate collapses, and so on). Crises that occur, depending on the reason they exist, can affect societies from different angles. For example, COVID-19 had a vital impact on human life due to being a health crisis. However, the currency crises that could arise due to the trade wars between the United States and China could have more of an economic impact. Societies are negatively affected in both cases.

Attention should also be drawn to an understanding that denies negativity in the definition of crises. It is emphasized, in both non-tourism and tourism literature, that crises also create opportunities (Schneider et al., 2010; Prideaux and McNamara, 2013). It is pointed out that the crisis does not only pose a danger or threat to individuals and organizations, but also creates new opportunities. However, this is not an element that will affect the definitions of crisis, because this situation shows that success can be achieved by thinking differently in the environment of economic, sociological and psychological negativities caused by the crisis, by analyzing the characteristics of the new environment and by using the new situation to the advantage of the organization. It can be said that it exemplifies a crisis management logic that will produce success stories from the negativity of the crisis, and more specifically, strategic ideas and solutions. Governments, organizations or businesses that adopt strategies that can turn crisis periods into opportunities can be more profitable in the long run. Similarly, the duration of the effects of crises on organizations for a short time or a long time depends on whether the organization takes measures that can counter the crisis in a timely manner. It is thought that this situation provides an opportunity for businesses that survive the crisis to become stronger (Aktan and Şen, 2001).

\subsubsection{Crisis Management}

Crisis periods are extraordinary processes that appear suddenly, are difficult to predict, complex to manage, and the effects of which are permanent and destructive. This imposes some responsibilities on the authorities in the management of public and private institutions. Unlike their routine duties and functions, organizations may need more than their competencies in matters such as special knowledge, skills and strategic perspectives during crisis periods. Crisis management for organizations means developing special measures and implementing special solutions to cope with the effects of the crisis (Devlin, 2007).

Glaesser (2003) states that crisis management is referred to as strategies, processes and measures planned and put into effect to prevent and deal with the crisis. In other words, crisis 
management is defined as a management process undertaken to overcome the current situation in the best way possible, and that occurs suddenly, disrupts routine life, where risks, depression, stress, tension and conflict increase, and managers have difficulty in making decisions (Tekin, 2016). As in both definitions, a crisis or an event is considered as a situation that has gone wrong. But equally important is how this situation is interpreted by crisis stakeholders, and how a decision is taken based on their interpretations. In other words, crisis management activities and practices are as important as the characteristics of the crisis (Gilpin and Murphy, 2008). Therefore, crisis managers want to manage the process effectively, even if they cannot prevent the crisis. For organizations implementing crisis management, this means focusing on a result that can be achieved between exiting the crisis with the least damage, and exiting the crisis with high benefit.

The word "crisis" means "disorganization." In other words, it can be said that the crisis is a normal or unstable situation. This term is treated as an emergency that occurs suddenly and breaks the routine processes of any system (İşyar, 2008). In the extraordinary crisis period that emerges in this context, countries, public or private institutions, or businesses should provide crisis management to fulfill routine functions, regardless of the crisis environment. The fact that the decisions to be taken, even if they are short-term, have long-term consequences shows how sensitive crisis management is for governments or organizations.

Crisis management not only takes into account the risk or possibility of an event but also includes the necessary actions during and after such an event. While crisis management is seen as an important part of ongoing operations by some organizations or institutions, it is not sufficiently taken into account by some businesses. However, organizations that fail to manage the crisis successfully are considered unlikely to survive in the long term or to suffer little damage (Hamidovic, 2012).

The COVID-19 pandemic, which has had an impact all over the world today, can be shown as an important example of how important crisis management is. In this period, steps such as increasing communication and information exchange between countries, health and food aid, and economic supports, show the decisions taken in crisis management. The increase in the relationship between the executive and legislative bodies of governments, better communication, and interaction with the public, and questions such as whether there is a need for intergovernmental cooperation, have gained importance during the COVID-19 crisis. Coping with the crisis in this suddenly evolving reactive environment is a matter of international crisis management. In this context, crisis management is of vital importance, regardless of the international, public or organizational scale of the crisis (Houben, 2004).

An important determinant in crisis management is the duration of the crisis. In this sense, in cases such as the 1999 earthquake in Turkey where the crisis moment is short term, Beirman (2003) draws attention to: (1) consolidation management efforts implemented for the period when the impact of the crisis is felt most strongly; and (2) post-crisis practices carried out when the effects become stable. It is not possible to suspend the economic activities and the flow of tourists to tourism destinations in case the crisis continues for a long time, such as long-term political instability due to ongoing conflicts in geographies such as Israel, Sri Lanka, and so on. In this case, attention is drawn to the fact that management and marketing strategies are applied under the crisis.

Crisis management emphasizes a proactive view, against reactive measures and regulations (Glaesser, 2003). The proactive vision includes predicting the crisis, establishing early warning systems, setting up and training crisis management teams, and solution-oriented 
practices that take advantage of opportunities when a crisis occurs. In this respect, crisis management processes can also be handled at different stages. Smith (1990) highlights three phases of the crisis: (1) the collapse phase, where the crisis potential (and the impact potential of the crisis) is established; (2) the operational phase of the crisis; and (3) the post-crisis phase. Reilly (1993), on the other hand, identified five steps of crisis management for businesses by surveying top managers: (1) problem detection and identification; (2) decision-making; (3) mobilization of resources and implementation; (4) information flow within the organization; and (5) external information flow. Taking into account the proactive approach and expanding the scope of the first two stages proposed by Smith (1990) regarding the occurrence of crises, crisis management processes can be expressed as: (1) pre-crisis (prediction and preparation phase); (2) crisis period (operation phase); and (3) post-crisis (wound healing phase).

At the basis of the understanding that looks reactive to crisis management lies the acceptance that crises are unexpected realizations. There is also a reactive approach to crisis management. Researchers representing this approach consider crises as unexpected and almost impossible to predict (Faulkner, 2001; Houben, 2004). Accordingly, the approaches of these studies within the scope of crisis management can be expressed as first-hand information after the crisis, common sense, and focus on a solution. It is understood that some studies consider the crisis as a predictable phenomenon (Pattillo and Berg, 1998; Greenwood et al., 2020).

The focus of these studies within the scope of crisis management is forecasting and the analysis of risk factors accordingly. In this respect, risk management and/or risk identification and measurement issues can also be associated with crisis management. Forecasting, on the other hand, may be related to the follow-up of some indicators: for example, data revealing environmental degradation, data showing the deepening of political problems, images explaining economic deterioration, and the effects of structural problems. Again, the most critical tool of the approach that sees forecasting as possible in crisis management is planning. A comprehensive crisis management plan is considered to be the main axis of managerial practices when faced with a crisis (Devlin, 2007).

One of the prominent areas of discussion when questioning crisis management is the security approach. Most of the consequences of crises create vital problems for people. Since these problems have many different facets, such as human security, food safety, health and employment or occupational safety, many studies evaluate the crisis together with the concept of security. These studies consider crisis management practices as security solutions (Pearson and Clair, 1998; Henderson, 1999).

The most important intellectual approach to the post-crisis phase is the regulation of the social environment. In the last stage covered by crisis management, solutions such as communication with the communities affected by the crisis, public aid in healing the wounds of the crisis, and so on, are frequently emphasized. This is related to the variety of social effects of crises. Mukherjee and Alpert (2006) draw attention to social problems in communities exposed to the crisis, emphasizing that the crisis disrupts social support networks. In this sense, it should especially be emphasized that crisis management should not overlook the humanitarian framework. The vital effects of the crisis depend on factors such as human dependence on the resources affected by the crisis, the severity of the crisis, the duration of the crisis and the interpretation of the crisis. It is also possible to perceive the first and last elements of these as a cultural context. In this case, it is necessary to understand that as well as the content and success of crisis management, the perception and interpretation of these managerial practices are also shaped in a cultural context. 


\subsubsection{Theories Related to Crisis Management}

The theoretical background regarding crises consists of two approaches. The first includes the theories that discuss the nature of the crisis and deal with the macro system elements that cause it. Crises can be viewed as abnormalities in a normally functioning system. The general equilibrium theory views crises as problems caused by external factors in the free market which tends to balance. Or, crises are perceived as a result of the market's immaturity (Clarke, 1994). In the face of this defense of the capitalist approach, Marxist theory regards the crisis as a natural result of capitalist development. In particular, it has been argued that the free market mechanism, which is considered to be stable and always evolving into equilibrium, is always vulnerable to crisis due to the underconsumption and the falling trend of profit rates. Keynes underlines that the lack of effective demand requires state intervention in the markets. Schumpeter's description of the crisis related to the fluctuating nature of capitalism and its unequal development process also reveals that crisis is inherent in capitalist development (Aydin and Araman, 2018). While theoretical economics studies and public administration and political science research inspired by this field relating to the nature of the crisis make their inquiries about the nature of the crisis accompanied by the assumptions of major theories, the literature that focuses on crisis management and looks at the issue more pragmatically and functionally represents the emergence of crisis management theories.

Sementelli (2007) divides the theoretical approaches within the scope of the management of disasters and crises into four: (1) decision theories; (2) management theories; (3) economic theories; and (4) social theories. In the context of decision theories, rational approaches, policies, standard operational principles, analytical predictions, geographic information systems are discussed. Within the scope of managerial theories, leadership, management, ethical and managerial responsibilities come to the fore. As for economic theories, resource allocations and economic impact systems are discussed. In the context of social theories, social structure, critical approach, postmodernity, a generations approach and marginalization issues come to the fore. While the issue of crisis management is also an evolving theoretical field, the relevant theoretical approaches mostly focus on crisis prediction, preparedness, response, planning and management; in this context, it appears to reflect contexts of informing the groups facing the crisis, mobilizing the actors exposed to the crisis to develop management by taking lessons from the crisis, and so on. Here, crisis management theories in the process of development and diversification are explained with a few examples.

\section{Problem and crisis management theory}

Crisis management not only involves a tactical response when a crisis begins, but also involves a complex and lengthy process. This process includes different actions such as crisis prevention, crisis preparedness, crisis intervention and recovery (Jaques, 2007). It can be seen that there is a close relationship between the crisis and the factor causing the crisis.

Problems and crises have a mutual relationship. A problem can create a crisis, and it can also offer a solution by creating another problem to deal with a crisis. If the problem is not dealt with effectively, it will grow into a crisis. In other words, if effective problem management is achieved, the probability of encountering a crisis is less. Therefore, there is a need to anticipate the problems that arise during the problem management process. Pre-crisis planning comes at the heart of the approach (Zamoum and Gorpe, 2018). 


\section{Situational crisis communication theory}

Situational crisis communication theory explains how the choice of response strategies in a crisis will take shape, and how crisis response strategies will have an impact on organizational reputation. Accordingly, the approach proposes to evaluate the crisis and choose an intervention strategy that fits the crisis. Thus, the organization will be able to protect its reputation source (Coombs and Holladay, 2002). The focus point of this theory is that governments or organizations adopt an empirical evidence-based approach across crisis strategies and types of crises to protect their reputation in the best way after the crisis.

Crisis managers want to protect their public reputation and values by using crisis communication. Situational crisis communication theory is an approach that involves predicting how stakeholders will respond to the damage that occurs in a crisis. Another factor that underlies organizations' adoption of this approach is situational analysis. Accordingly, another aim of the theory is to analyze how people will react to the intervention strategies used to manage the crisis from the perspective of managers (Coombs, 2007b). There are three goals of focusing on corporate reputation in developing crisis intervention strategies. These are: (1) shaping the characteristics of the crisis; (2) changing the public and stakeholders' perception of the organization; and (3) reducing the negative impact of the crisis (Coombs, 1995).

\section{Association theory}

In essence, this theory examines the connection between crisis and public relations, the factors causing the crisis, and how people perceive the crisis period. When a negative event occurs, people question why this unexpected period occurred. In the aforementioned crisis periods, the responsibilities of people and all other relevant environmental factors in the emergence of the crisis are questioned (Zamoum and Gorpe, 2018). Here, determining the responsibility for dealing with the crisis is essential. According to the theory, people adopt an emotional approach towards crisis and prefer to examine the responsible element by investigating the causes of events. According to the theory of associations, it is said that people attribute responsibility to the events and environments that cause the crisis. According to this approach, people look for reasons for negative and sudden events (Weiner, 1985), because crises are unexpected and destructive processes. Here, managers make a situational assessment to deal with the crisis (Coombs, 2007a).

\subsection{CRISIS AND TOURISM}

\subsubsection{Crises Affecting Tourism}

Tourism is a dynamic industry that increases income, employment, investment, exports, and thus promotes economic growth. Tourism is also recognized as an important sector for the economic and social transformation of countries and communities with limited assets (Visser and Ferreira, 2013). Likewise, tourism is one of the most important strategic sectors of many developing countries. Economic growth, disposable income, increased free time, political stability and increases in tourism campaigns have accelerated the growth of international tourism. After a significant recession in 2009 , tourism has managed to recover strongly again (Haque, 2016). 
Factors such as established international relations, intercultural interaction, shaping the global society, understanding and peace among people, developed living standards, local trade and development, protection of heritage and tradition, are possible with tourism activities in a region (Visser and Ferreira, 2013). However, these ties established through tourism can be affected very quickly and deeply by emerging crises. The human factor in the production and consumption side of tourism, which is a service industry, can be considered as the reason why it experiences harsh effects in reactive periods such as crisis.

The travel and tourism industry, by its very nature, is very sensitive to crises arising from economic, political, social, technological and other factors at the national and global levels. Therefore, both travel and tourism suffered greatly from various crises (Henderson, 1999). It is possible that an extraordinary development in a region of the world can immediately affect travel decisions relating to that region. Developments in digitalization and information communication technologies make every corner of the world more interdependent and connected. Therefore, even regional risks negatively affect the ongoing travel and tourism dynamism across large geographies. For example, the Gulf Wars in 1991 and 2003 significantly reduced travel for tourism purposes in many parts of the world (Ritchie, 2004).

As a result of the global economic crisis, the hotel and tourism industry experienced a serious decline in sales and profitability, especially in 2009. In many parts of the world, hotels experienced a decline in occupancy, average daily price and income per room. At the same time, the decline seen in demand has created pricing power for customers (Tania, 2011).

Terrorism also creates a crisis environment for tourism. This is because touristic activities take place in a safe environment. In this sense, as terrorist acts destroy the perception of a safe environment, touristic activities cannot take place in areas where terrorist acts occur. A crisis occurs, as tourists cannot avoid security concerns. Another situation where people have security concerns is health. After Severe Acute Respiratory Syndrome (SARS) appeared in Guangdong Province of China in February 2002, it turned into another crisis process affecting tourism. The number of visitors to Hong Kong declined to the lowest level in 12 years. The number of tourists in Hong Kong, which was 1.33 million the previous year, was only around 427000 (Pine and McKercher, 2004).

Natural disasters can cause serious damage to tourism as well. Sudden natural disasters can cause a complete crisis period by creating great damage. For example, the tsunami of December 26, 2004 hit the coastal areas of countries around the Indian Ocean, bringing death and destruction on an unimaginable scale. Almost 300000 people died, and the economic cost of the disaster exceeded $\$ 10$ billion. The lost lives of tourists from the West caused great damage to the region in terms of tourism (Sharpley, 2005).

As can be seen in all these examples, any crisis, regardless of its cause, has serious effects on tourism and can cause damage. Table 1.1 includes some of the important crises that have been experienced, and that have harmed tourism. Thus, addressing the damage caused by different crisis factors to societies from different perspectives will contribute to a better understanding of the crisis issue.

\subsubsection{Economic Effects of Crises on Tourism}

Various crises affecting every aspect of social life have an impact on tourism. However, the most important reason why the tourism sector is affected is the pressure of the crises on the economy. For this reason, it would not be wrong to say that the effects of crises on tourism 


\section{COVID-19 and the hospitality and tourism industry}

\section{Table 1.1 Crises affecting tourism}

\begin{tabular}{|c|c|c|}
\hline Crisis & Place - Time & Effects \\
\hline $\begin{array}{l}\text { Luxor terrorist } \\
\text { attacks }\end{array}$ & $\begin{array}{l}\text { Egypt - November, } \\
1997\end{array}$ & $\begin{array}{l}\text { - Terrorists killed } 62 \text { European tourists at Luxor Temple. } \\
\text { - Serious losses were experienced in the tourism demand for the country. }\end{array}$ \\
\hline $\begin{array}{l}\text { Foot and Mouth } \\
\text { disease }\end{array}$ & $\begin{array}{l}\text { United Kingdom } \\
(\mathrm{UK})-2001\end{array}$ & $\begin{array}{l}\text { - } 10 \text { million livestock were slaughtered in the UK to eradicate the Foot and Mouth } \\
\text { Disease epidemic. } \\
\text { - Although no human infections were confirmed, fear of infection caused great } \\
\text { damage to the UK in terms of tourism in } 2001 \text {. } \\
\text { - Tens of thousands of people were laid off. }\end{array}$ \\
\hline September 11 attacks & $\begin{array}{l}\text { United States (US) - } \\
\text { September, } 2001\end{array}$ & $\begin{array}{l}\text { - } 2973 \text { people died in four separate aircraft attacks. } \\
\text { - Domestic and international airline transportation in the USA stopped for days. } \\
\text { - Job losses in tourism and tourism-related jobs were enormous and lasted for years. } \\
\text { - Overseas international travel to the US (excluding Canada and Mexico) has still not } \\
\text { reached the year } 2000 \text { level, as of } 2020 \text {, even after nine years. }\end{array}$ \\
\hline
\end{tabular}

SARS China - November, $\quad-8096$ cases of SARS were reported and 774 deaths were confirmed in 37 countries.

$2002-$ Airline transportation and tourism decreased significantly, especially in Asia.

- Recovery started in the third quarter of 2003.

Indian Ocean tsunami Indian Ocean -

- Approximately 230000 people died on two continents from the tsunami caused by

December, 2004 the earthquake reaching 9.3 magnitude and its aftershocks.

- In the short term, tourism suffered major falls and financial losses, and tens of

thousands of people in the sector were unemployed. However, within a year, most of the tourism economy recovered.

Pandemic (H1N1) Mexico - April, 2009 - A new flu virus, easily transmitted from person to person, was first detected in Mexico in April 2009.

- Within six weeks, the virus spread to dozens of countries and was declared an epidemic in the summer.

- In total, less than 20000 people died from the virus.

- Travel and tourism activities declined sharply due to human-to-human transmission and high media coverage.

- Mexico's economic loss alone was more than $€ 3$ billion, half of which was in the travel and tourism sector.

- International travel and tourism figures reached the pre-2009 pandemic (H1N1)

levels only in the spring of 2010.

Haiti Earthquake

Haiti - January, 2010 - More than 200000 people died when the 7.3 magnitude earthquake hit the capital, Port Au Prince, and its surroundings.

- More than 100000 people were injured and more than 1 million people were left homeless.

- Tourism was regarded as one of the bright spots in the country's economy and employment picture before the earthquake. 


\begin{tabular}{lll}
\hline Crisis & Place - Time & Effects \\
\hline COVID-19 & China - December, & - The new type of coronavirus that emerged in Wuhan, passing from person to \\
(Pandemic) & person, spread to many countries in a short time. \\
& - On March 11,2020, the outbreak was declared as the COVID-19 pandemic. \\
& - As of May $30,2020,5796257$ cases were confirmed. \\
& - As of June 2020,362483 people had died in 216 countries from the epidemic, \\
& which is still uncontrollable. \\
& - The COVID-19 outbreak caused a $22 \%$ drop in international tourist arrivals in the \\
& first three months of 2020. \\
& - In the year 2020, a decrease of between $60 \%$ and $80 \%$ in tourism is predicted. \\
& - Worldwide, around 100 million to 120 million people's jobs in tourism and related \\
& industries are considered to be at risk. \\
& - A loss of between $\$ 910$ million and $\$ 1.2$ trillion is expected. \\
& - It is estimated that there will be around 580 million to 1.1 billion less individuals \\
& participating in tourism worldwide. \\
\hline
\end{tabular}

Sources: Based on UNWTO (2012), WHO (2020a).

are mostly related to economic factors and dimensions. The fact that most of the crises have a negative impact on the spending tendency of the consumer sector, resulting in shrinkage in tourism demand, is a good example of this. In this regard, it is useful to address these spheres of influence in a way that can lead to an understanding of the mechanism by which crises affect tourism.

\section{Demand shrinkage}

A tourism product is perceived as a product with a wide range of substitution possibilities. In times of crisis, the substitution effect increases exponentially. Potential tourists can, on the one hand, give up travel as an individual decision; on the other hand, the opportunity to travel may be lost due to the measures taken in the face of the crisis, such as international travel restrictions. In this respect, depending on the effects of crises, many social, psychological, economic, legal and political reasons facilitate the substitution of tourism products. Consequently, serious shrinkages in demand occur as a result of: (1) a decrease in disposable income in the market and/or the risk of a future decrease in disposable income; (2) an increase in demand for more vital products, and/or an expectation that the demand for such products will increase; (3) an increase in the cost of the tourism product; (4) an increase in non-monetary costs of participation in tourism; (5) participation in tourism considered to be risky due to health and safety concerns; and (6) legal travel restrictions due to risk perception. It has been observed that the COVID-19 pandemic, which has produced serious global effects since 2019, triggered almost all of these factors and eventually brought international travel restrictions onto the agenda, dramatically reducing the demand for tourism.

Another important event affecting international tourism in recent years is considered to be the 2008-09 financial crisis and the subsequent global economic recession. This led to a 4 percent and a 6 percent reduction in international tourist arrivals and revenues, respectively, in 2009 compared to 2008 (COMCEC, 2017).

During the period of the global economic crisis that started in the USA in 2008 and spread around the world, Northern and Western Europe, North and Central America, and South Asia were affected by the sharp decline in international tourist flows (UNWTO and ILO, 
2013). The number of flight connections between Europe and Asia decreased by 4 percent in 2008 and around 6 percent in 2009. A 20 percent decrease is mentioned at the beginning of 2008 for travel agencies (IATA, 2010). In terms of the crises that decreased the demand for tourism, the Gulf War in 1991 and the Kosovo conflict in 1999 should be mentioned. The crisis that emerged as a result of the wars triggered a significant slowdown in the growth of current tourism. However, after the Gulf War in 1991, while international tourism grew by 1.2 percent, it managed to increase by 8.3 percent in 1992 (UNWTO, 2001).

The SARS crisis also had serious effects on tourism. In Australia alone, there was a 4.2 percent decrease in tourists participating in international travel in 2003. The net decline in real gross domestic product (GDP) in Australia in 2003 was \$34 981 million. The decrease in the number of tourists visiting the country (a \$109 196 million decrease in real GDP) played a major role in this situation. Canada lost $\$ 1.5$ billion of GDP, including tourism income of about $\$ 1.1$ billion, in 2003 after the crisis (Simpson, 2009).

Hurricane Katrina, which hit the southern coast of the United States, is considered as another crisis that had negative effects on tourism. The hurricane wreaked havoc on coastal areas and 80 percent of New Orleans was submerged. The hurricane also had a devastating effect on tourism in the region. As a result of Hurricane Katrina, the tourism industry in New Orleans alone lost about $\$ 5$ billion. Before the hurricane, in 2004, New Orleans was visited by 10.1 million tourists. After the hurricane in 2006, the number of visitors was 3.7 million (Tomić et al., 2013).

\section{Destabilization and exchange rate fluctuations}

In geographies affected by the crisis, the destabilization of economic variables is reflected in production, and fluctuations in the exchange rate occur. The close relationship between tourism demand and the exchange rate is a known phenomenon (Crouch, 1993). The depreciation of the national currency reflects positively on the tourism-trade balance (Dogru et al., 2019) and increases the demand for the destination. However, the exchange rate fluctuation is often a phenomenon that develops with other economic problems such as inflation, and can disrupt the functioning of the economy and produce extensive negative effects. It can prevent the development of tourism in terms of infrastructure and superstructure by increasing investment costs at the destination. On the other hand, it will lead to a shrinkage in domestic demand due to inflationary effects. The depreciation of the currency of the countries sending tourists is reflected as shrinkage in demand for tourism. In this respect, it can be said that the destabilization of the economic environment in the framework produced by the crises is reflected in the exchange rate regimes in the short term, and this affects participation in tourism significantly.

The USA-origin global crisis in 2009 caused economic instability in many countries around the world. During the crisis period, it was reported that GDP fell by 7.3 percent in Greece, foreign debt increased to 182.2 percent and unemployment to 16.3 percent, and civil servants' wages decreased by around 30-40 percent (Tania, 2011).

The killing of 58 foreign tourists and four Egyptians in Luxor by terrorists in November 1997 created another tourism crisis. After this crisis, the tourism industry, of primary importance to the Egyptian economy, suffered greatly. Hence, the crisis destabilized Egypt economically. Before the November massacre, Egyptian tourism had reached approximately 4.2 million visitors and $\$ 4$ billion in revenues in 1997. The number of international travelers coming to Egypt after the attack decreased by 12.8 percent. Economic stability in the country suffered greatly, as the Luxor attack cost Egypt about 50 percent of its annual revenues (Glaesser, 2006). 


\section{Employment loss}

As a labor-intensive sector, the first losses in tourism when facing a crisis are usually in employment. Reducing the workforce emerges as an important tactical option for businesses that focus on reducing costs in a crisis. For example, during the 2008-09 economic crisis, the decrease in production increase in the United States was 4.5 percent. In addition, 800000 people per month had to quit their jobs during the peak period of this crisis. During this period, employment loss in the USA was around 10 percent. On the other hand, the crisis resulting from COVID-19 has caused 50 percent of people to worry about losing their jobs (Baldwin and Mauro, 2020). The impact of the 2008-09 economic crisis on employment was devastating. During the crisis, many businesses, including private companies as well as public institutions, found the solution was to lay off workers in the face of decreasing demand. As a result of this situation, unemployment rates reached around 205 million globally in 2009 (International Labour Office, 2011).

Another example is the September 11, 2001 attacks. Major travel cancellations occurred in the tourism industry following the attacks. The airlines affected by economic slowdown made personnel cuts following the 2001 attacks. Accommodation establishments were closed, and a temporary loss of capacity and workforce was observed. Boeing laid off 30000 people, and Rolls-Royce (in the production of aircraft engines) 5000 people. European and Asian stock markets reacted downwards in the first days. During the crisis period, losses of airline companies were around US\$10 billion: US\$7 billion on international routes, and US\$3 billion on domestic routes. Between September 11 and 14, Amadeus reservations decreased by 28 percent and Galileo reservations by 40 percent (UNWTO, 2001). The impact of the COVID-19 pandemic on the tourism industry is estimated to cost nearly $\$ 1$ trillion, and more than 100 million employees will lose their jobs worldwide (Durkee, 2020).

\section{Loss of capital}

A coherence between foreign direct investments in countries and the development of tourism has been determined for different destinations (Habibi, 2015; Satrovic and Muslija, 2019). It remains uncertain whether crises reduce the interest of foreign investors. However, crises create opportunities for foreign capital, making it advantageous for both foreign and domestic capital to increase their profits, suppress the labor sector and impose their conditions (Dufour and Orhangazi, 2009). In other words, while crises create attractive conditions for foreign investors and encourage foreign investments, they also create an effect that reduces the contribution of these investments to the destination. The ambiguous relationship between foreign investments and crises in tourism (Steiner, 2010) can also be evaluated accordingly.

The crisis that broke out in East and Southeast Asian countries in the second half of 1997 affected many countries economically. Currency devaluations and falling property prices in countries reduced the acquisition costs of fixed assets such as land, buildings and capital goods produced. Also, the decline in the value of many Asian firms after the financial crisis made it easier to buy firms. For example, in Thailand, foreign direct investment purchases in the first quarter of 1998 were 30 percent higher than the previous year (UNCTAD, 1998). After the reopening of the American Wall Street stock market after the September 11 attacks, insurance companies, air transport companies and tourism companies recorded serious declines (UNWTO, 2001). Although this situation is seen as an incentive for foreign investment, it means the loss of power of enterprises and industry due to the decrease in stocks in the short term. 
Again, with COVID-19, the crisis that occurred in global economies significantly affected capital movements. It is expected that the capital flow in global markets will decrease during 2020 and foreign direct investment will decrease by 30 percent compared to the previous year. In this period when the capital needs of countries increase, foreign and domestic capital flows are linked to the health and economic policies implemented (OECD, 2020a). In another report, it is predicted that foreign direct investment will decrease between by 5 percent and 15 percent globally in 2020, depending on the COVID-19 crisis (UNCTAD, 2020).

\subsubsection{Strategies for Coping with the Crisis in Tourism}

The multidimensional effects of crises have created the approaches and application patterns chosen in response to the crises within the scope of the crisis management approach. These patterns are sometimes presented in the form of recommendations for dealing with the crisis, and sometimes they are exemplified as the successful implementation of specific destinations.

\section{Suggestions for coping with the crisis in tourism}

The most successful strategy for a tourism destination during or before a crisis can be thought of as "security." This is because tourism is often an optional activity, and it is quite easy for the tourist to find alternative ways to spend time and money. If visitors perceive a risk, they may give up going to destinations or even on vacation. Therefore, the most important condition for the tourist to participate in the trip is security, because people are not inclined towards destinations where war, terrorism, and so on are in question (Sönmez et al., 1999).

Another important point to be considered in terms of management and the success of the process during crisis periods should be the active and effective use of communication channels. The communication element, which is one of the most noteworthy issues in crisis periods, is of particular importance. Crises are periods that change routine life in unexpected ways. In these extraordinary situations, the tourism industry has to use information communication technologies effectively to prevent an atmosphere of panic, and disinformation (Glaesser, 2006). For example, tourists who have dealt with terrorist attacks before await detailed and up-to-date information on their next trip to the same destination. At this point, the tourism industry must provide this information effectively and quickly. Another suggestion for the tourism industry or destinations facing terrorist acts is the steps taken during the crisis period. Away from the scene of the attack, the accommodation of existing tourists can be changed, updated information to current and potential tourists can be given, and security solutions can be provided (Hajibaba et al., 2016).

During the crisis period after disasters such as earthquakes in a tourism destination area, management measures can be expressed as another important precaution group. In this context, after the Indian Ocean tsunami in 2004, governments, public and private organizations took various measures. The death of 227898 people in the tsunami made it necessary to take some steps to determine the responsibilities of people in another similar crisis. Governments chose to set up an alert system that predicts the tsunami. Signs to the nearest tsunami evacuation point were placed on land surrounding most streets and shores. Private companies and associations initiated various programs to address accommodation and food needs during the crisis in these regions (Bagans and Tapola, 2011). At the same time, in the face of natural disasters, transporting tourists to accommodation far from the epicenter of the disaster is among the most 
emphasized suggestions. The realization of fast and effective transfer can reduce the burden of whoever is responsible for public opinion after the crisis period (Hajibaba et al., 2016).

Various suggestions are offered to deal with crises. The success factors against a crisis in tourism in COMCEC (2017) are as follows:

- Tourists who feel a personal connection to a country can donate money to the relevant country or make a visit to support the industry in crises such as natural disasters, and so on. In this context, destinations must build customer loyalty.

- One of the most successful recovery strategies is leadership in understanding policy and market trends, as well as government support to the industry.

- Cooperation is important in times of crisis. In cases where the public and private sectors work together and are supported by the general public, the recovery from the crisis is rapid.

- Liberalizing excessive bureaucratic procedures and introducing incentives to encourage foreign investment would be a strong stance against the crisis.

According to Akova et al. (2011), crisis strategies that can affect tourism should be addressed by governments and tourism firms. Accordingly, parties on both sides should take precautions and prepare an action plan to deal with the crisis. Governments can accelerate the industry's recovery by responding to shocks in the tourism industry. In this context, states can follow crisis strategies such as tax cuts, compensation to tourism companies and related industries, increased insurance premiums, late payment of excise taxes, and compensation to employees in tourism. Governments can save many businesses from bankruptcy by announcing an aid package that can help the tourism industry to recover. On the other hand, tourism companies can develop measures such as reorganizing working hours, flexibility in the number of customers and employees, flexibility in investment decisions and flexibility in business processes. Tourism companies can introduce themselves to new markets and change their marketing strategies according to the domestic and global markets.

\section{Strategies applied to cope with the crisis in tourism}

\section{Indonesia}

Many crises have occurred affecting Indonesian tourism. However, the Bali bombings in 2002 and 2005 are regarded as the crises that had the greatest impact. International visitor arrivals decreased by 11 percent and 6 percent, respectively. Thereupon, the Indonesian government set up a crisis management team to recover the damaged image of the tourism industry. The government first implemented security measures. Subsequently, police, tourism and hospitality employees, media, healthcare professionals and representatives from host communities came together to participate in terrorism-focused security and crisis training. Also, the government, which initiated campaigns to remove travel restrictions from neighboring countries, succeeded in acting with a crisis management logic. The decisions taken were mostly determined by the crisis management team. Indonesian tourism, which grew over ten years as a result of the crisis management and policies adopted, reached 10407 million tourist visits in 2015 (COMCEC, 2017).

\section{Sri Lanka}

After the 2004 tsunami, the Sri Lankan government initiated various activities to cope with the crisis. Accordingly, the government enacted a Disaster Management Law, established 
the National Council for Disaster Management and the Reconstruction and Development Agency. The government also established three new ministries: the Ministry of Resettlement, the Ministry of National Construction and Real Estate Infrastructure Development, and the Ministry of Disaster Management and Human Rights. The government encouraged tourist product diversification by declaring a festival every month of the year. The government, which launched a public relations campaign to promote domestic and foreign tourism in 2011, was successful: tourism today is considered the fastest-growing industry in the country (COMCEC, 2017).

\section{Tunisia}

Twenty-two people died in Tunisia as a result of the attack on the Bardo National Museum in March 2015 (BBC, 2015). Following the attack, a 25 percent drop in Tunisia tourism and 35 percent less revenue resulted in 2015. Thereupon, the government started protests and propaganda against terrorism with the support of thousands of people. The Nobel Peace Prizes given to many Tunisian leaders and the participation of many European leaders in these demonstrations brought significant success to the government's public relations work. The Ministry of Tourism and Crafts brought together various regional stakeholders related to tourism to adopt an approach on how to create a common strategy for development. Subsequently, tourists coming from neighboring countries to support the demonstrations contributed to the revival of tourism. Investments by companies such as Marriott, Hilton and Movenpick contributed to the rapid and effective recovery in tourism. Today, the authorities continue their comprehensive marketing efforts. As well as Europe, the state also manages marketing campaigns for Russia, Eastern Europe, North Africa, China and the Middle East (COMCEC, 2017). Tunisia managed to overcome the impact of the attack by welcoming 7 million visitors in 2017 (Reuters, 2018).

\subsubsection{Evaluation of Crisis Management Studies in Tourism from a Future Perspective}

The literature on the crisis in tourism, although there are studies which are exceptions, reveals certain common perspectives. It can be said that both through the studies investigating the effects of the crisis on tourism (Solomon and George, 1976; Hope, 1980), and those highlighting the concepts of planning and policy against the crisis (Arbel and Bargur, 1980), the crisis and crisis management studies are mostly focused on economic results, and were developed to identify the tools that can be developed to manage these results. This situation transforms the crisis management literature into a one-dimensional discussion platform, which requires the multidimensional thinking and application system of social sciences with this field. In this context, the topics and possible research subfields that the crisis management literature will likely address in the future can be exemplified as follows:

- In the context of the industrial effects of the crises, the reasons, the short-term effects of demand and supply are mostly emphasized. However, crises change human attitudes and behaviors in the long run by causing serious psychological traumas and shocks. In this respect, the industrial crisis studies focusing on psychological consequences is considered important.

- Crises highlight crisis management and solutions, which validates a pragmatic and sometimes an opportunist attitude. The corrosive and negative effects on other stakeholders of 
this prominent attitude for businesses are ignored. This situation makes it inevitable for us to consider a discussion of crisis ethics.

- The fact that crisis-related solutions generally focus on financial support packages also suggests the necessity of human-centered solutions in the long term. It is not just financial assets that are lost. In this sense, crisis management should include human counseling and institutionalize it.

\subsection{COVID-19 AND ITS EFFECTS ON TOURISM}

\subsubsection{COVID-19 and Its Effects as a Global Crisis}

An epidemic that will affect the whole world was announced by official sources for the first time on December 31, 2019. Chinese health officials reported to the World Health Organization (WHO) that they had encountered an unprecedented case in Wuhan city of Hubei province, and that it posed a risk of becoming an epidemic by spreading every day. Since then, Wuhan has been at the center of an unprecedented coronavirus epidemic. The World Health Organization stated on March 11, 2020 that the COVID-19 epidemic had spread to more than 114 countries and regions worldwide, infecting more than 118000 people and causing 4291 deaths. In this context, the WHO declared the COVID-19 outbreak as a "pandemic" (WHO, 2020b). As of September 17, 2020, there were 29444198 COVID-19 cases worldwide, and 931321 people had died (WHO, 2020a).

\subsubsection{Effects on Tourism Demand}

The pandemic has turned into a global crisis due to health concerns. Governments have closed international borders to prevent the epidemic, and most countries have imposed curfews. Therefore, the closed international borders and the restrictions imposed have caused an unprecedented shrinkage in demand and a sharp decline in tourism. People think that going out on the street is not safe, let alone going on vacation. In this context, tourism has been one of the most damaged industries in the global crisis caused by the epidemic.

Out of 217 destinations worldwide, 156 (72 percent) had completely stopped international tourism as of April 27, 2020. Restrictions had been continuing for at least three months in 25 percent of the destinations and at least for two months in 40 percent. Eighty-three percent of European destinations, 80 percent in America, 70 percent in Asia and the Pacific, 62 percent in the Middle East, and 57 percent in Africa had completely closed their borders to international tourism (UNWTO, 2020c).

The COVID-19 outbreak caused a 22 percent drop in international tourist arrivals in the first three months of 2020. Based on the figures in the first quarter of the year, a tourism decrease between 60 percent and 80 percent is predicted for 2020. Due to the global economic crisis in 2009 , international tourist arrivals decreased by 4 percent; and during the SARS epidemic in 2003, tourism experienced a decline of only 0.4 percent (UNWTO, 2020a).

It is predicted that the biggest decrease in tourism movements in 2020 will be in May and that tourism movements will increase gradually after June. It can be said that there will be more tourism participation in the last quarter of the year. In the current scenarios for 2020, 


\section{COVID-19 and the hospitality and tourism industry}

a tourism decline of up to 80 percent is expected in the worst case, or a tourism loss of 60 percent at best (UNWTO, 2020b).

The COVID-19 pandemic has slowed down international economic activity since the day it was first diagnosed, and has seriously damaged global economic growth. The pandemic is expected to regress global economic growth by 3-6 percent in 2020; the worst economic figures experienced since the Great Depression of the 1930s (Jackson et al., 2020). In addition to accommodation and travel businesses, all touristic businesses with close human interaction, such as restaurants and entertainment venues, faced a serious shrinkage in demand. A loss of $\$ 113$ billion is predicted in international airlines (Maliszewska et al., 2020). It is estimated that there will be around 580 million to 1.1 billion less individuals participating in tourism worldwide (UNWTO, 2020b).

The Organisation for Economic Co-operation and Development (OECD) states that in the first and second wave of the COVID-19 outbreak, per capita real income will decrease by 8 percent and 9.5 percent, respectively, in all economies in 2020. It states that even if there is an economic recovery in 2021, real income per capita can only be as much as in the year 2013 (OECD, 2020b).

\subsubsection{Effects on Tourism Employment}

Around 100 million to 120 million people's jobs in tourism and related industries worldwide are considered to be at risk (UNWTO, 2020b). In 2020, it is estimated that 63.4 million people working in tourism in the Asia Pacific, 13 million in Europe, 8 million in North America, and more than 100 million people working in tourism worldwide will lose their jobs (Figure 1.1).

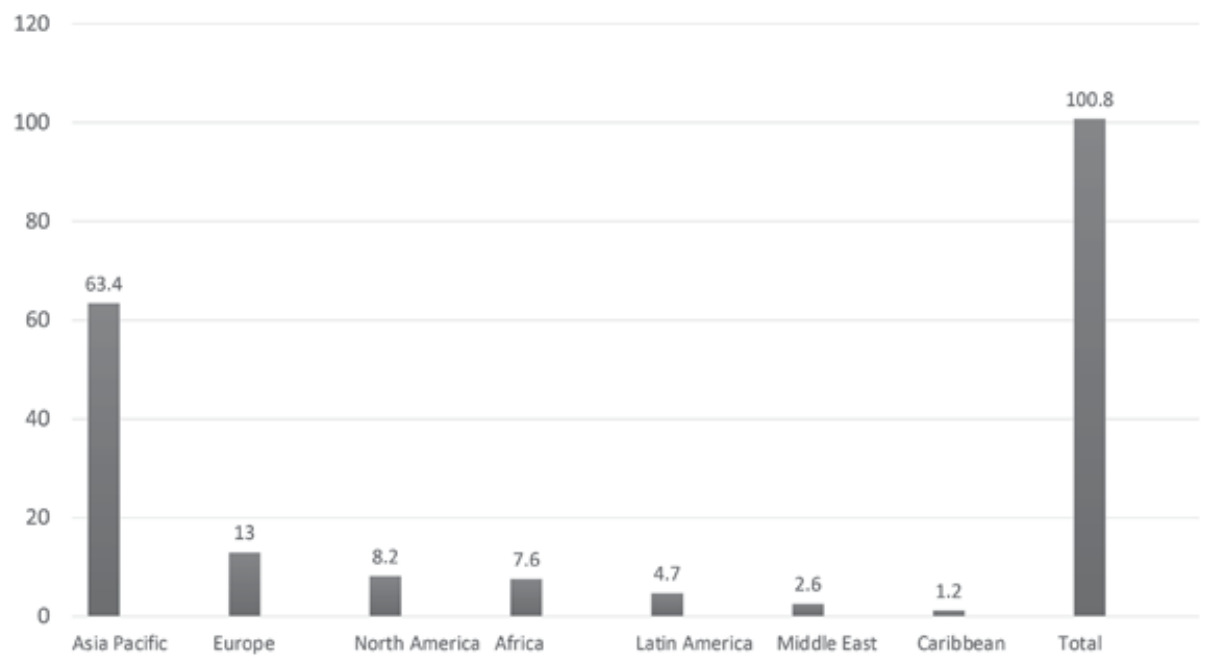

Figure 1.1 Predicted employment loss in the travel and tourism industry for 2020 (COVID-19) 
Demand-related losses have contributed to the peak of global unemployment in the last 25 years. Considering the second wave of the pandemic, global unemployment is assumed to be between 9.2 and 10 percent by the end of 2020. Global trade is predicted to decrease by 18 percent. This situation will seriously harm developing economies dependent on trade, especially in terms of employment (Jackson et al., 2020).

\subsubsection{Investment and Other Economic Effects}

Due to COVID-19, it is stated that investment rates (public and private) in the economies are at their lowest level in the last ten years. Direct investment rates of gross national product (GNP) in OECD countries between 2015 and 2019 are 4 percent on average. Due to the crises that occurred occasionally in this period, the numbers declined to 2 percent. However, it is stated that depending on the COVID-19 outbreak, these figures may even be below 2 percent by the end of 2020 (OECD, 2020b).

The International Monetary Fund (IMF) has drawn attention to the monetary and foreign exchange policies of countries that want to overcome the negative economic effects of the pandemic crisis. Developed economies have preferred to reduce the effects of the current crisis by tightening their monetary policies to prevent capital losses. On the other hand, developing countries have tended to relax their monetary policy to maintain the adjustment in exchange rates. Countries wanted to prevent the crisis by taking unconventional monetary policy measures such as providing liquidity injections, government and corporate bonds. Developing-country economies have taken extraordinary measures such as price controls and export restrictions to facilitate credit and financial regulation on the economic front of the pandemic (Mühleisen et al., 2020).

A loss of $\$ 910$ million to $\$ 1.2$ trillion is expected in tourism-related exports (UNWTO, 2020b). Due to the shrinkage in tourism demand, the decrease in exports caused by tourism faces not only the tourism sector but also many related sectors with a deteriorating supplydemand balance.

The numbers mentioned above indicate what a major crisis was caused by the COVID-19 outbreak. Also, these figures explain the sensitivity of the tourism industry to crises that may arise. It can be seen that COVID-19 is the biggest crisis the global world has witnessed in recent years, which threatens human lives and disrupts daily life, hits many sectors, particularly the hospitality and travel industry by closing international borders, and regresses economies within the framework of employment and capital losses.

\section{CONCLUSION}

Tourism is one of the sectors that crises affect most, in the shortest time and most deeply. In the face of its sensitivity to a crisis, tourism also gives the appearance of a flexible and highly reversible industry, because it is also very skilled in eliminating the effects of the crisis as soon as possible. This situation is related to the structure of tourism and the ability of tourism actors (investors, employees, suppliers, and so on) to produce a flexible business mentality and agile responses. At the same time, the proactive approaches developed concerning the crisis, the best practices, and the cooperation, common action and communication efforts that are 
familiar to the industry, play an important role in the determination to continue and develop commercial relations.

It can be said that crisis management in tourism is based on understanding the crisis conditions well, staying in contact with the related parties, especially with the consumer population, directing the demand with the right information and acting according to the solution decisions produced, and not making any stakeholders suffer. However, in this process it should be emphasized that besides the urgent focus on matters concerning the crisis, there is also a need to develop humanitarian and ethical sensitivity.

Different theories regarding the scope of crisis management have been put forward in most studies dealing with current practices. This may incorporate various variables depending on the variety of crises and diversification of management approaches in crisis periods. There is a need for studies that look at crises from different perspectives.

The COVID-19 outbreak is a good example of studies related to the management of crises. During the epidemic, which affects tourism in every aspect, the size, the depth, the areas of influence and the actions of the actors will be examined repeatedly. Although it may be thought that a crisis that produces such large-scale effects is unlikely to occur, and the findings related to this crisis can be considered as an exception, what happened during the epidemic process, the practices and the efforts made will shed light on the future of crisis management discussions.

\section{REFERENCES}

Akova, O., Sarış1k, M., \& Dönmez, D. (2011). Strategies for tourism industry under the global economic crisis: A SWOT analysis of Turkish tourism. International Conference on Eurasian Economies, ss. 382-389, Kirgizistan.

Aktan, C.C., \& Şen, H. (2001). Ekonomik kriz: nedenler ve çözüm önerileri. Yeni Türkiye, Ekonomik Kriz Özel Saylsl, 42(2), 1225-1230.

Arbel, A., \& Bargur, J. (1980). A planning model for crisis management in the tourism sector, European Journal of Operational Research, 5(2), 77-85.

Aydın, Y., \& Araman, S. (2018). Konjonktür ve kriz teorileri: Marks, Keynes ve Schumpeter. Nişantaşı üniversitesi Sosyal Bilimler Dergisi, 6(1), 45-67.

Bagans, L., \& Tapola, H. (2011). Crises in the tourism industry and their effects on young travellers. Haaga-Helia University of Applied Science, Bachelor's thesis degree programme in tourism.

Baldwin, R., \& di Mauro, B.W. (2020). Mitigating the COVID economic crisis: act fast and do whatever it takes. CEPR Press.

BBC (2015, May 20). Tunisia bardo museum attack: Man arrested in Italy. BBC News. Retrieved from https://www.bbc.com/news/world-africa-32809851.

Beirman, D. (2003). Restoring tourism destinations in crisis: a strategic marketing approach. CABI Publishing.

Blake, A., \& Sinclair, M.T. (2003). Tourism crisis management: US response to September 11. Annals of Tourism Research, 30(4), 813-832.

Clarke, S. (1994). Marx's theory of crisis. Macmillan Press.

COMCEC (2017). Risk and crisis management in tourism sector: recovery from crisis in the OIC member countries. COMCEC coordination office, August, 1-149.

Coombs, W.T. (1995). Choosing the right words: The development of guidelines for the selection of the "appropriate" crisis-response strategies, Management Communication Quarterly, 8(4), 447-476. https://doi.org/10.1177/0893318995008004003.

Coombs, W.T. (2007a). Attribution theory as a guide for post-crisis communication research. Public Relations Review, 33(2), 135-139. https://doi.org/10.1016/j.pubrev.2006.11.016. 
Coombs, W.T. (2007b). Protecting organization reputations during a crisis: the development and application of situational crisis communication theory. Corporate Reputation Review, 10(3), 163-176. https://doi.org/10.1057/palgrave.crr.1550049.

Coombs, W.T., \& Holladay, S.J. (2002). Helping crisis managers protect reputational assets: Initial tests of the situational crisis communication theory. Management Communication Quarterly, 16(2), 165-186. https://doi.org/10.1177/089331802237233.

Crouch, G.I. (1993). Currency exchange rates and the demand for international tourism. Journal of Tourism Studies, 4(2), 45-53.

Çakar, K. (2018). Critical success factors for tourist destination governance in times of crisis: A case study of Antalya, Turkey. Journal of Travel and Tourism Marketing, 35(6), 786-802.

Devlin, E.S. (2007). Crisis management planning and execution. Auerbach Publications.

Dogru, T., Isik, C., \& Sirakaya-Turk, E. (2019). The balance of trade and exchange rates: Theory and contemporary evidence from tourism, Tourism Management, 74, 12-23.

Dufour, M., \& Orhangazi, Ö. (2009). The 2000-2001 financial crisis in Turkey: A crisis for whom? Review of Political Economy, 21(1), 101-122

Durkee, A. (2020). Tourism industry faces $\$ 1$ trillion loss, 100 million jobs at risk from COVID-19, UN Reports. Retrieved from Forbes website: https://www.forbes.com/sites/alisondurkee/2020/08/25/un -report-tourism-industry-covid-19-faces-1-trillion-loss-100-million-jobs-at-risk/\#961 fc88cdd32.

Faulkner, B. (2001). Towards a framework for tourism disaster management. Tourism Management, 22(2), 135-147.

Ghaderi, Z., Som, A.P.M., \& Wang, J. (2014). Organizational learning in tourism crisis management: an experience from Malaysia. Journal of Travel and Tourism Marketing, 31(5), 627-648.

Gilpin, D.R., \& Murphy, P.J. (2008). Crisis management in a complex world. Oxford University Press.

Glaesser, D. (2003). Crisis Management in the Tourism Industry. Butterworth-Heinemann.

Glaesser, D. (2006). Crisis management in the tourism industry, 2nd edition. Routledge.

Greenwood, R., Hanson, S.G., Shleifer, A., \& Sørensen, J.A. (2020). Predictable financial crises, Harvard Business School Working Paper, 31(20), 3307-3343.

Habibi, F. (2015). Foreign direct investment, tourism and economic growth in Malaysia. European Journal of Social Sciences, 48(3), 381-390.

Hajibaba, H., Boztuğ, Y., \& Dolnicar, S. (2016). Preventing tourists from canceling in times of crises. Annals of Tourism Research, 60, 48-62. https://doi.org/10.1016/j.annals.2016.06.003.

Hamidovic, H. (2012). An introduction to crisis management. ISACA Journal, 5, 1-4.

Haque, M.Z. (2016). The impact of economic crisis on tourism industry: A Bangladesh perspective. International Research Journal of Engineering, IT and Scientific Research, 2(1), 28-46.

Henderson, J.C. (1999). Managing the Asian financial crisis: Tourist attractions in Singapore. Journal of Travel Research, 38(2), 177-181. https://doi.org/10.1177/004728759903800212.

Henderson, J.C. (2007). Managing tourism crises. Butterworth-Heinemann.

Hope, K.R. (1980). The Caribbean tourism sector: recent performance and trends. International Journal of Tourism Management, 1(3), 175-183.

Houben, M. (2004). International crisis management: The approach of European states. Routledge.

IATA (2010), International Air Transport Assocation Annual Report 2010. June, Berlin.

International Labour Office. (2011). Global employment trends 2011: The challenge of a jobs recovery. Geneva.

İşyar, Ö.G. (2008). Definition and management of international crises. Perceptions, 13(3), 1-48.

Jackson, J., Weis, M., Schwarzenberg, A., \& R. Nelson (2020). Global economic effects of COVID-19. Congressional Research Service, September.

Jaques, T. (2007). Issue management and crisis management: An integrated, non-linear, relational construct. Public Relations Review, 33(2), 147-157.

Jiang, Y., Ritchie B., \& Benckendorff, P. (2019). Bibliometric visualisation: An application in tourism crisis and disaster management research, Current Issues in Tourism, 22(16), 1925-1957.

Koselleck, R., \& Ritcher, M.W. (2006). Crisis. Journal of the History of Ideas, 48(2), 357-400.

Laws, E., Prideaux, B., \& Chon, K.S. (eds) (2007). Crisis management in tourism. CABI Publishing.

Maliszewska, M., Mattoo, A., \& Van der Mensbrugghe, D. (2020). The potential impact of COVID-19 on GDP and trade: A preliminary assessment. Policy Research Working Paper No. WPS 9211, World Bank Group. 
Mansfeld, Y., \& Pizam, A. (eds) (2006). Tourism, security and safety from theory to practice. Elsevier Butterworth-Heinemann.

Milašinović, S., \& Kešetović, Ž. (2008). Crisis and crisis management: A contribution to a conceptual and terminological delimitation. Megatrend Revija, 5(1), 167-185.

Mukherjee, P.P., \& Alpert, J.L. (2006). Overview of psychological interventions in the acute aftermath of disaester. In: Barbanel, L. and Sternberg, R.J. (eds), Psychological interventions in times of crisis. Springer Publishing Company.

Mühleisen, M., Gudmundsson, T., \& Ward, H.P. (2020). COVID-19 response in emerging market economies: Conventional policies and beyond. IMF Blog. Retrieved from: https://blogs.imf.org/2020/08/ 06/covid-19-response-in-emerging-market-economies-conventional-policies-and-beyond/.

OECD (2020a). Policy Responses to Coronavirus (COVID-19), Foreign direct investment flows in the time of COVID-19. Retrieved from: https://www.oecd.org/coronavirus/policy-responses/foreign -direct-investment-flows-in-the-time-of-covid-19-a2fa20c4/.

OECD (2020b). OECD Economic Outlook. Organisation for Economic Co-operation and Development, 2020 (1), Paris.

Paraskevas, A. \& Altinay, L. (2013). Signal detection as the first line of defence in tourism crisis management, Tourism Management, 34, 158-171.

Park, D., Kim, W.G., \& Choi, S. (2019). Application of social media analytics in tourism crisis communication. Current Issues in Tourism, 22(15), 1810-1824.

Pattillo, M.C.A., \& Berg, M.A. (1998). Are currency crises predictable? A test. Working Paper of the International Monetary Fund.

Pearson, C.M., \& Clair, J.A. (1998). Reframing crisis management. Academy of Management Review, 23(1), 59-76.

Pine, R., \& McKercher, B. (2004). The impact of SARS on Hong Kong's tourism industry. International Journal of Contemporary Hospitality Management, 16(2), 139-143.

Prideaux, B., \& McNamara, K.E. (2013). Turning a global crisis into a tourism opportunity: The perspective from Tuvalu. International Journal of Tourism Research, 15, 583-594.

Quarantelli, E.L. (1988). Mine disaster crisis management. Journal of Management Studies, July, $586-589$.

Reilly, A.H. (1993). Preparing for the worst: The process of effective crisis management. Industrial and Environmental Crisis Quarterly, 7(2), 115-143.

Reuters (2018). Tunisia expect record number of tourists, up to nine million in 2019 - Reuters. November 13. Retrieved from: https://uk.reuters.com/article/tunisia-economy-tourism/tunisia-expect -record-number-of-tourists-up-to-nine-million-in-2019-idUKL8N1XN6XM.

Ritchie, B.W. (2004). Chaos, crises and disasters: A strategic approach to crisis management in the tourism industry. Tourism Management, 25(6), 669-683.

Satrovic, E., and Muslija, A. (2019). Causality relationship between foreign direct investment and tourism. International Journal of Economic and Administrative Studies, 22, 65-76.

Schneider, F., Kallis, G., \& Martinez-Alier, J. (2010). Crisis or opportunity? Economic degrowth for social equity and ecological sustainability. Introduction to this special issue. Journal of Cleaner Production, 18, 511-518.

Scott, R. (1988). Managing crisis in tourism: A case study of Fiji. Travel and Tourism Analyst, 6, 57-71.

Sementelli, A. (2007). Toward a taxonomy of disaster and crisis theories. Administrative Theory and Praxis, 29(4), 497-512.

Sharpley, R. (2005). The tsunami and tourism: A comment. Current Issues in Tourism, 8(4), 344-349.

Simpson, D. (2009). How badly will influenza affect tourism economy? Retrieved from: https://www .cabi.org/leisuretourism/news/19458.

Smith, D. (1990). Beyond contingency planning: towards a model of crisis management. Industrial Crisis Quarterly, 4(4), 263-275.

Solomon, P.J., \& George, W.R. (1976). An empirical investigation of the effect of the energy crisis on tourism. Journal of Travel Research, 14(3), 9-13.

Sönmez, S., Apostolopoulos, Y., \& Tarlow, P. (1999). Tourism in crisis: Managing the effects of terrorism. Journal of Travel Research, 38(1), 13-18.

Steiner, C. (2010). An overestimated relationship? Violent political unrest and tourism foreign direct investment in the Middle East. International Journal of Tourism Research, 12(6), 726-738. 
Tania, S. (2011). The impact of economic crisis on tourism and hospitality: Results from a study in Greece. Central European Review of Economics and Finance, 1(1), 1-5. Retrieved from: http://eureka .lib.teithe.gr:8080/bitstream/handle/10184/2887/Financial crisis kapiki.pdf?sequence=1.

Tekin, Ö. (2016). Kriz Yönetimi ve Kamu Yönetimi İçin Ōnemi. Selçuk Üniversitesi Sosyal Bilimler Meslek Yüksek Okulu Dergisi, 18(2), 119-135.

Tomić, N., Gavrilov, M.B., Božić, S., Stojsavljević, R., \& Marković, S.B. (2013). The impact of Hurricane Katrina on the United States Tourism Industry. European Researcher, 51(5-4), 1581-1590.

UNCTAD (1998). The financial crisis in Asia and foreign direct investment: An assessment. Switzerland.

UNCTAD (2020). Coronavirus could shrink global FDI by $5 \%$ to $15 \%$. Retrieved from: https://unctad .org/en/pages/newsdetails.aspx?OriginalVersionID $=2299$.

UNWTO (2001). Tourism after 11 September 2001: Analysis, remedial actions and prospects. London.

UNWTO (2011). Toolbox for Crisis Communications in Tourism. Madrid.

UNWTO (2012). Toolbox for Crisis Communications in Tourism - Checklists and Best Practices (Russian version). September 20.

UNWTO (2020a). COVID-19 tourism recovery technical assistance package for tourism recovery. May 12. Retrieved from: https://www.unwto.org/news/unwto-releases-a-covid-19-technical-assistance -package-for-tourism-recovery.

UNWTO (2020b). Global guidelines to restart tourism. May 28. Retrieved from: https:/www.unwto.org/ restarting-tourism.

UNWTO (2020c). UNWTO Remains at a standstill as $100 \%$ of countries impose restrictions on travel. May 11. Retrieved from: https://www.unwto.org/news/covid-19-world-tourism-remains-at-a -standstill-as-100-of-countries-impose-restrictions-on-travel.

Visser, G., \& Ferreira, S. (2013). Tourism and crisis: a never-ending story? In: Visser, G. and Ferreira, S. (eds), Tourism and Crisis. Routledge. https://doi.org/10.4324/9780203114049.

Weiner, B. (1985). An attributional theory of achievement motivation and emotion. Psychological Review, 92(4), 548-573.

WHO (2020a). Coronavirus disease (COVID-19) pandemic. September 17. Retrieved from: https://www .who.int/emergencies/diseases/novel-coronavirus-2019.

WHO (2020b). WHO Director-General's opening remarks at the media briefing on COVID-19 - 11 March 2020. Retrieved from: https://www.who.int/dg/speeches/detail/who-director-general-s -opening-remarks-at-the-media-briefing-on-covid-19---11-march-2020.

World Tourism Organization and International Labour Organization (UNWTO and ILO) (2013). Economic crisis, international tourism decline and its impact on the poor. Madrid.

WTTC (2020). WTTC now estimates over 100 million jobs losses in the Travel \& Tourism sector and alerts G20 countries to the scale of the crisis. April 24. Retrieved from: https://wttc.org/News-Article/ WTTC-now-estimates-over-100-million-jobs-losses-in-the-Travel-\&-Tourism-sector-and-alerts-G20 -countries-to-the-scale-of-the-crisis.

Zamoum, K., \& Gorpe, T.S. (2018). Crisis management: A historical and conceptual approach for a better understanding of today's crises. In: Holla, K. (ed.), Crisis Management-Theory and Practice. IntechOpen. DOI: 10.5772/intechopen.76198. 